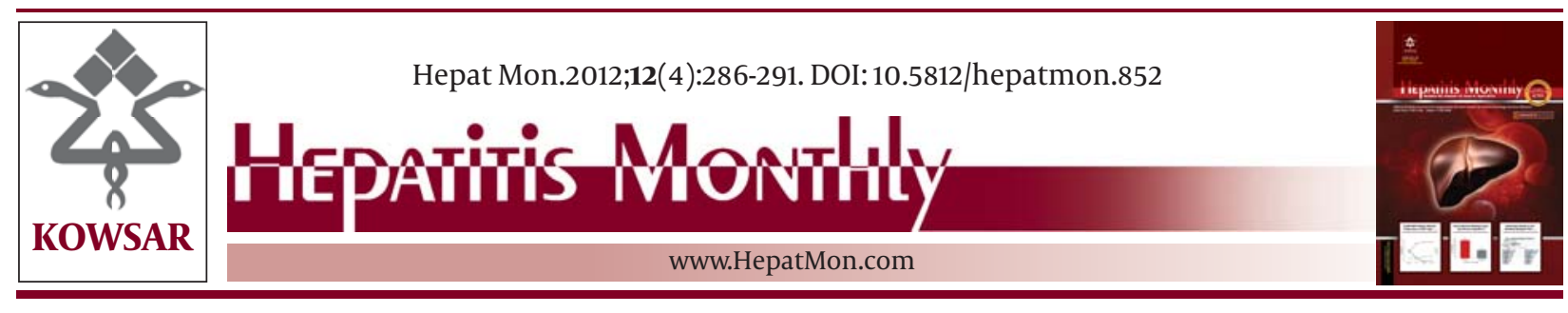

\title{
Transfusion Transmitted Hepatitis: Where Do We Stand Now? A One Center Study in Upper Egypt
}

\author{
Amel Abdel Magied El-Faramawy ${ }^{{ }^{*}}$, Omnia Fathy El-Rashidy ${ }^{1}$, Perihan Hamdy Tawfik ${ }^{2}$, \\ Galal Helmy Hussein ${ }^{1}$ \\ ${ }^{1}$ The Pediatrics Department, Faculty of Medicine, Ain Shams University, Cairo, Egypt \\ ${ }^{2}$ The Clinical Pathology Department, Faculty of Medicine, Ain Shams, University, Cairo, Egypt
}

\begin{tabular}{l}
\hline A R T I C L E I N F O \\
\hline Article type: \\
Original Article \\
\hline Article history: \\
Received: 22 Sep 2011 \\
Revised: 01 Feb 2012 \\
Accepted: 02 Mar 2012 \\
\hline
\end{tabular}

\section{Keywords:}

Child

Hepatitis

Transfusion

Egypt

\begin{abstract}
A B S T R A C T
Background: Despite progress made in the prevention of transfusion-transmitted infections (TTI) over the last few years, they continue to be a problem in many parts of the world, particularly in multitransfused patients.

Objectives: The aim of this study was to estimate the prevalence of hepatitis B virus (HBV), hepatitis C virus (HCV), and to evaluate the screening and vaccination program among our cohort of multitransfused children from Qena, Upper Egypt.

Patients and Methods: One-hundred children suffering from diseases requiring repeated blood transfusions were included in the study. They were classified into group 1, which included 67 children with thalassemia, and group 2, which included 33 children with hemophilia. Screening for hepatitis B surface antigen, hepatitis B surface antibody, hepatitis B core antibody and antibody to HCV was done using a second-generation enzyme-linked immunosorbent assay technique.

Results: Only 12\% of all patients were either acutely or chronically infected with HBV. $46 \%$ were immune due to previous vaccination, whereas $39 \%$ of patients were not protected from HBV infection. HCV antibodies were positive in $45 \%$ of cases. Seventy-eight patients had a complete hepatitis B vaccination in the form of three doses as documented by birth certificate. Thirty-six patients mentioned history suggestive of hepatitis. The prevalence of the studied hepatitis markers was similar in both the thalassemia and hemophilia groups of children.

Conclusions: Transfusion-transmitted hepatitis is still a major problem for multitransfused children in Egypt. More effort is required to reduce the infection rate through proper screening of blood and blood products, strict emphasis on receiving the vaccine, regular follow-up for those children with a hepatitis B antibody titer, and providing booster doses for those in need. Copyright $\odot 2012$ Kowsar Corp. All rights reserved.
\end{abstract}

Implication for health policy/practice/research/medical education:

As Egypt is a country of intermediate prevalence regarding HBV and of high prevalence regarding HCV infection, great effort should be made to prevent and control these infections .updating the knowledge about the prevalence of these infections particularly among the high risk groups is important to assess the efficacy of preventive measures and to highlight weak points in the strategy aiming to decrease the infection rate. This study is recommended to all clinicians involved in treatment of polytransfused patients for better outcome.

\section{- Please cite this paper as:}

El-Faramawy AA, El-Rashidy OF, Tawfik PH, Hussein GH. Transfusion Transmitted Hepatitis: Where Do We Stand Now? A One Center Study in Upper Egypt. Hepat Mon. 2012;12(4): 286-291. DOI: 10.5812/hepatmon.852

* Corresponding author: Amel Elfaramawy, 15, Abou Elmahassen st, Roxy,

Heliopolis, Cairo, Egypt. Tel: +02-0105208292, Fax: +02-22912647, E-mail:

amelhome4@gmail.com

DOI:10.5812/hepatmon.852

Copyright @2012 Kowsar Corp. All rights reserved. 


\section{Background}

Regular blood transfusions improve the overall survival of multitransfused children but despite the progress made in preventing transfusion-transmitted infections (TTIs) over the last few years, TTIs continue to be a problem in many parts of the world (1). Blood transfusion is the main risk factor for transmitting viral hepatitis, particularly in patients with hematological diseases (2).The TTI problem is directly proportional to the prevalence of infection in the blood donor community (3). Patients with thalassemia commonly receive transfusions and, thus, are exposed to transfusion-associated infections. Among these infections, hepatitis B and hepatitis $C$ are the most common (4). Hepatitis B is an important infection in patients with thalassemia and prevention by vaccination is necessary. The immunological response to hepatitis B vaccine in polytransfused patients with thalassemia requires additional research attention (5). Although the risk of post-transfusion hepatitis $C$ virus (HCV) infection dropped significantly after the national screening of blood in 1993, more than $20 \%$ of children who were multitransfused after that date were HCV-RNA positive (6). Monitoring infectivity markers in multitransfused patients is an important indicator of the efficiency and quality of testing in blood centers (7).

\section{Objectives}

The objective of the study was to estimate the prevalence of hepatitis B virus (HBV) and HCV antibodies among multitransfused children registered at the blood bank of Red Crescent Hospital in Qena (Upper Egypt) to update the prevalence of HBV and HCV infections among multitransfused children and to evaluate the impact of serological screening and the vaccination program on the prevalence of those infections.

\section{Patients and Methods}

This cross-sectional study included 100 children attending the children's blood bank established to serve children at Red Crescent Hospital. The children were suffering from diseases that require repeated blood transfusions. This study was conducted according to the recommendations of the Ethics Committee of Children's Hospital, Ain Shams University. Informed consent was obtained from the children's guardians. Among the 100 included patients, 67 had thalassemia and constituted group 1, 33 patients were hemophiliacs and constituted group 2. The groups were subjected to a complete history stressing the duration of transfusion therapy, blood source (Red Crescent blood bank or multiple centers), frequency of transfusion, history of vaccination against hepatitis B, and a history suggestive of hepatitis. A thorough clinical examination was performed, emphasizing the presence or absence of jaundice and size of the liver and spleen. Five cc of venous blood was collected from each patient during regular follow-up using a sterile plastic syringe. One cc was mixed with EDTA and used for a complete blood count (CBC). The blood samples were centrifuged for 10 minutes. The remaining serum was used to measure aspartate transaminase (AST), alanine transaminase (ALT), and total and direct bilirubin levels. The remaining serum was placed in sterile covered storage tubes and stored at $-30^{\circ} \mathrm{C}$ until collection of all samples. Screening for the hepatitis B surface antigen (HBsAg), hepatitis B surface antibody, and hepatitis B core antibody ( $\mathrm{HBc} \mathrm{Ab})$ was conducted using a secondgeneration enzyme-linked immunosorbent assay (ELISA) technique with commercial kits provided by ADALTIS (Guidonia di Montecelio, Rome, Italy) Screening for antibody to HCV (anti-HCV) was performed using a second generation ELISA technique with commercial kits provided by Diasorin (Saluggia (Vercelli), Italy).

\subsection{Statistical Analysis}

Descriptive and analytical statistics were performed using the Excel 2003 software package (Microsoft Inc., Redmond, WA, USA). Data are presented as mean \pm SD and range. Categorical data are presented as numbers and percentages. Comparisons between the groups were made using the Mann-Whitney $U$-test for non-parametric data (z-values). Associations between categorical parameters were performed with the chi-square test. Values of $P$ $<0.05$ were considered significant.

\section{Results}

The patients included in the study ranged in age from 4-15 years with a mean of $8.29 \pm 3.16$ years. There were 68 (68\%) males and 32 (32\%) females. Their disease duration ranged from 2 to 13 years with a mean of $6.45 \pm 3.11$ years. Children with thalassemia were treated with transfusions of packed red blood cells (RBCs), chelation therapy, and a splenectomy, if indicated. Children with hemophilia received either fresh frozen plasma or cryoprecipitate. The transfused blood or blood product units (packed RBCs unit $=300 \mathrm{ml}$, plasma unit $=250 \mathrm{ml}$, and cryoprecipitate unit $=15 \mathrm{ml}$ ) ranged from 16 to 149 units with a mean of $66.90 \pm 33.69$ units through the entire disease duration. Forty-four patients received blood or blood products from the Red Crescent blood bank at Qena, and 56 patients (56\%) received blood from multiple centers. Seventy-eight patients had complete hepatitis B vaccinations in the form of three doses as documented by birth certificate, and 22 patients (22\%) had incomplete vaccination of hepatitis B (missing one or two doses). Thirtysix patients mentioned a history suggestive of hepatitis. Fifty-one of the patients were on chelation therapy due to high serum ferritin levels (>1000 $\mathrm{ng} / \mathrm{dl}$ ), and 23 patients $(23 \%)$ were splenectomized, as they were all di- 


\begin{tabular}{lll}
\hline Table 1. Hepatitis Markers For the Studied Cases & & \\
\hline Hepatitis Markers & Cases, No. (\%) $(\mathbf{n = 1 0 0})$ & Significance \\
\hline $\begin{array}{l}\text { HBs Ag: negative } \\
\text { HBs Ab: positive }\end{array}$ & $46(46)$ & Indicating Immunity because of hepatitis B vaccination \\
HBc Ab: negative & $7(7)$ & Indicating chronic infection \\
HBs Ag: positive & & \\
HBs Ab: positive & $5(5)$ & Indicating that they are acutely infected \\
HBc Ab: negative & & \\
$\begin{array}{l}\text { HBs Ag: positive } \\
\text { HBs Ab: negative }\end{array}$ & $3(3)$ & Immune because of natural infection \\
HBc Ab: positive & & \\
HBs Ag: negative & $39(39)$ & Susceptible (not immune) to HBV infection \\
HBs Ab: positive & & \\
HBc Ab: positive & & Indicating recent or past infection with HCV \\
HBs Ag: negative & $45(45)$ & Have co infection \\
HBs Ab: negative & $12(12)$ & \\
HBc Ab: negative & & \\
HCV Ab: positive & & \\
Positive for both HBs Ag and HCV Ab & &
\end{tabular}

agnosed with thalassemia. As shown in Table 1, 12\% of all patients were positive for HBsAg and were either acutely (5\%) or chronically (7\%) infected with hepatitis B. In total, 46 patients were immune due to vaccination and three were immune due to previous infection, whereas 39\% of patients were not protected from HBV infection. HCV antibodies were positive in 45 cases and coinfection by hepatitis B and C was present in 12. Eight males and four females were positive for HBsAg. Their mean age was 11.2 \pm 3.3 years with a mean disease duration of $8.5 \pm 3$ years.
Seven/12 were not completely vaccinated. Thirty-two males and 13 females had positive HCV antibodies. Their mean age was $7.7 \pm 2.8$ years with a mean disease duration of $3.5 \pm 1.9$ years. Children positive for HBsAg were significantly older than those who were positive for HCV $(P<0.001)$. They also had a longer disease duration $(P<$ $0.001)$ and received more blood or blood products units $(P<0.05)$.

No relationship was found with the blood source.

Patients were classified into two groups. Group 1 includ-

\begin{tabular}{|c|c|c|c|}
\hline & Group 1 & Group 2 & $P$ value \\
\hline Age, y, mean \pm SD & $7.64 \pm 2.93$ & $8.94 \pm 3.29$ & $<0.05$ \\
\hline Disease duration, $\mathrm{y}$, mean \pm SD & $5.62 \pm 2.63$ & $7.27 \pm 3.35$ & $<0.05$ \\
\hline Received blood, units, mean \pm SD & $50.94 \pm 23.57$ & $82.86 \pm 34.92$ & $<0.001$ \\
\hline AST, IU/L, mean \pm SD & $32.14 \pm 21.11$ & $47.32 \pm 24.40$ & $<0.05$ \\
\hline ALT, IU/L, mean \pm SD & $35.84 \pm 19.09$ & $47.70 \pm 29.42$ & $>0.05$ \\
\hline T bilirubin, mg/dL, mean \pm SD & $2.90 \pm 1.16$ & $2.26 \pm 0.91$ & $<0.05$ \\
\hline D bilirubin, $\mathrm{mg} / \mathrm{dL}$, mean $\pm \mathrm{SD}$ & $1.06 \pm 0.74$ & $1.42 \pm 0.76$ & $<0.05$ \\
\hline Indirect bilirubin, $\mathrm{mg} / \mathrm{dL}$, mean $\pm \mathrm{SD}$ & $1.84 \pm 0.95$ & $0.84 \pm 0.57$ & $<0.001$ \\
\hline Source of transfused blood, No. (\%) & & & $>0.05$ \\
\hline $\begin{array}{l}\mathrm{RCB}^{\text {a }} \text { only } \\
\text { multiple sources }\end{array}$ & $\begin{array}{l}31(46) \\
36(54)\end{array}$ & $\begin{array}{l}13(39) \\
20(61)\end{array}$ & \\
\hline History of HB Vaccination, No. (\%) & & & $>0.05$ \\
\hline $\begin{array}{l}\text { Incomplete } \\
\text { Complete }\end{array}$ & $\begin{array}{l}12(18) \\
55(82)\end{array}$ & $\begin{array}{l}9(27) \\
24(73)\end{array}$ & \\
\hline History suggestive of hepatitis & & & $>0.05$ \\
\hline Negative & $42(63)$ & $22(67)$ & \\
\hline Positive & $25(37)$ & $11(33)$ & \\
\hline
\end{tabular}




\begin{tabular}{|c|c|c|c|c|}
\hline Hepatitis Markers & Interpretation & Group 1, No. $(\%)(n=67)$ & Group 2, No. (\%) $(n=33)$ & Pvalue \\
\hline HBs Ag: Negative & Immune due to vaccination against HBV & $31(46)$ & $15(46)$ & $>0.05$ \\
\hline \multicolumn{5}{|l|}{ HBs Ab: Positive } \\
\hline \multicolumn{5}{|l|}{ HBc Ab: Negative } \\
\hline HBs Ag: Positive & Chronically infected & $3(4)$ & $4(12)$ & $>0.05$ \\
\hline \multicolumn{5}{|l|}{ HBs Ab: Positive } \\
\hline \multicolumn{5}{|l|}{ HBc Ab: Negative } \\
\hline HBs Ag: Positive & Acutely infected & $3(4)$ & $2(6)$ & $>0.05$ \\
\hline \multicolumn{5}{|l|}{ HBs Ab: Negative } \\
\hline \multicolumn{5}{|l|}{ HBc Ab: Positive } \\
\hline HBs Ag: Negative & Immune due to natural infection & $2(3)$ & $1(3)$ & $>0.05$ \\
\hline \multicolumn{5}{|l|}{ HBs Ab: Positive } \\
\hline \multicolumn{5}{|l|}{ HBc Ab: Positive } \\
\hline HBs Ag: Negative & Not immune, at risk \& need vaccination & $28(42)$ & $11(33)$ & $>0.05$ \\
\hline \multicolumn{5}{|l|}{ HBs Ab: Negative } \\
\hline \multicolumn{5}{|l|}{ HBc Ab: Negative } \\
\hline HCV Ab: Positive & Recent or past infection with HCV. & $32(48)$ & $13(39)$ & $>0.05$ \\
\hline HBs Ag \& HCV Ab & Coinfection & $7(10)$ & $5(15)$ & $>0.05$ \\
\hline
\end{tabular}

ed 67 patients with ß-thalassemia and group 2 included 33 patients with hemophilia. Table 2 shows a comparison of the studied parameters between the two groups.

Patients in group 2 were significantly older and had a prolonged disease duration compared to those in group 1. Significantly more blood or blood products units were received by group 2 patients compared to those in group $1(P<0.001)$. AST $(\mathrm{IU} / \mathrm{L})$ and direct bilirubin $(\mathrm{mg} / \mathrm{dl})$ were significantly higher in group 2 than those in group 1 , whereas significantly higher total bilirubin $(\mathrm{mg} / \mathrm{dl})(P$ $<0.05)$ and indirect bilirubin $(\mathrm{mg} / \mathrm{dl})(P<0.001)$ levels were observed in group 1 compared to those in group 2 (Table 2).

The prevalence of the hepatitis markers was similar in the thalassemia and hemophilia groups of children ( $\mathrm{Ta}$ ble 3).

\section{Discussion}

In 1992, Egypt started a universal immunization program in infants. The schedule adopted by the Egyptian Ministry of Health was three doses of yeast-recombinant hepatitis B vaccine administered to all infants at 2, 4, and 6 months to coincide with other compulsory vaccines (8). However, complete hepatitis B vaccination in our study (as documented by birth certificate) was achieved in 78 patients, whereas 22 patients had incomplete vaccination (missed one or two doses). This result suggests that the vaccination schedule requires additional effort to ensure that the entire population has strictly completed their vaccinations, particularly in the high-risk groups of patients. We also found that among all polytransfused children in our study that one-third of those who completed their vaccinations were not protected. This could be explained by the fact that a certain percentage of those who received vaccinations will be non-responsive or hyporesponsive to the HBV vaccine; this is particularly true for patients with chronic liver disease (9), renal disease, or patients undergoing hemodialysis, as these patients lose hepatitis B immunity after natural infection or vaccination (10). The prevalence of HbsAg in polytransfused patients was high before the era of vaccination, as shown in different studies, and it varies in different places according to prevalence in the community. Amarapurkar et al. (11) studied children with thalassemia for HBsAg in India in 1992. The results were positive in $45 \%$ of their patients. In 1993, a study among Egyptian children with thalassemia showed that HBsAg positivity was $16.48 \%$ (12). After establishing a vaccination program against hepatitis $\mathrm{B}$, there was a notable impact on the prevalence of hepatitis B infection rate. Al-Shayyab et al. (13) showed HBsAg seropositivity in $3.5 \%$ of patients with hereditary hemolytic anemia in a study conducted in Jordan in 2001 . Irshad et al. (14) reported that $18 \%$ of children with thalassemia were positive for HBsAg in India in 2002. In 2005, Khakhkhar and Joshi (15) conducted a study on children with thalassemia also in India and found that only $6.6 \%$ were positive for HBsAg. A very low prevalence of positive HBsAg was found in multi-transfused patients with $\beta$-thalassemia major or intermedia and sickle cell anemia in a 2006 Turkish study by Ocak et al. (16), as only 0.75\% were HBsAg positive. Among 50 patients with thalassemia, hepatitis B virus infection occurred in one patient (2\%) in Cairo in 2009 (17). 
The decrease in the prevalence of hepatitis B infection reflects the efficacy of the vaccination program and effective screening of blood and blood products. Despite the decline in the prevalence of HBsAg among Egyptian polytransfused children over the past 20 years, it is still high compared to other geographical areas, and this could be attributed to the high infection rates among those children despite vaccination against $\mathrm{HBV}$, as they might not have responded adequately to vaccination or may not be fully vaccinated. Post-vaccination infections may be a result of viruses harboring surface (S)-gene mutations in a region critical for antibody reactivity to the hepatitis B surface antigen (anti-HBs). Furthermore, the burden of infection in the community plays a role, as Egypt has intermediate levels of HBV infection (2-7\% chronic infection) (18). Although blood is screened for HBV in blood banks in Egypt, blood-related HBV transmission may occur, because screening in most blood banks is performed only for HBsAg but not for core antibodies or ALT. El Zayadi et al. (19) called for implementing the anti-HBc test as a routine assay, which would certainly eliminate possible HBV-infected blood units, as rejection of these units would be beneficial to decrease the risk of HBV transmission, particularly in immunocompromised recipients. Several published studies have reported the prevalence of HCV among polytransfused patients in different areas over the world. Khalifa et al. (20) reported HCV prevalence of 85\% in Egypt in 1993, and the prevalence of HCV in Egypt in 1997 was 69\% among polytransfused children and 55\% among blood donors (21). The prevalence of HCV positivity in New Delhi in 1998 was 57\% (22). In Denmark, $56 \%$ of polytransfused patients were HCV positive in 2002 (23), whereas in Iran Ansar et al. (24) found HCV antibodies in $63.8 \%$ of their polytransfused patients. The reported prevalence of hepatitis C antibodies in Italy was $40.7 \%$ in 2002 (25). Darwish et al. (26) studied the geographic distribution of HCV sero-positivity in patients with thalassemia in Egypt and found that $46.2 \%$ in the Delta region were $\mathrm{HCV}$ positive, which is the highest prevalence in Egypt compared to 38.6\% in Big Cairo and 37.8\% in Upper Egypt. In Iran in $2008,16.9 \%$ of children with thalassemia, were anti-HCV positive (27), whereas in Khuzestan Province, southwest Iran, $28.1 \%$ of patients with thalassemia were HCV positive in 2009 (28). However, the HCV prevalence was $41.7 \%$ in a study by Hussain et al. (29) conducted in Pakistan in 2008. In the Middle East, the prevalence of $\mathrm{HCV}$ among patients with thalassemia has been remarkably stable at 40-70\% from 1993 to 2001. The highest prevalence has been reported in Egypt at $75.6 \%$ and the lowest at $40 \%$ in Bahrain. In Jordan, HCV prevalence was $40.5 \%$ (13), whereas in Lebanon, $14 \%$ of patients were positive for HCV (25). In Saudi Arabia, a prevalence of 26\% was reported in 2002 (30), while in $2011,1.1 \%$ of multitransfused children had hepatitis B surface antigen, 3.5\% were anti-HCVpositive, and none were anti-HIV-positive (31). The current and future burden of diseases caused by viral hepatitis in
Egypt is significant. It is not an exaggeration to say that viral hepatitis (particularly HCV) is currently and will remain Egypt's most pressing public health issue for some time. HBV accounts for $10-30 \%$ of chronic liver disease, and there is a large occult reservoir of HCV causing chronic liver disease (32). Omar et al. (33) concluded that despite the decrease in HCV antibody prevalence from $71 \%$ to $51.7 \%$ in 1995 , HCV infection still represents a major health problem for patients with thalassemia, which requires more attention and effort. The high prevalence of $\mathrm{HCV}$ in our study was expected, because the prevalence of $\mathrm{HCV}$ among the Egyptian population is one of the highest in the world. The screening for HCV by ELISA, which is used in Egypt, is not very accurate, and many countries are using better techniques for screening donated blood for viruses by recombinant immunoblot assay and polymerase chain reaction techniques. Moreover, the donor could be in a window period during which infection may not be detected serologically (34). In our study, $39 \%$ of patients with hemophilia were HCV positive, which is lower than what was found in a study conducted in Brazil, whereas $44.6 \%$ of the hemophilic population was positive (35), but higher than the results found by Asif et al. (36), in Pakistan, where $36 \%$ of patients with hemophilia A and B tested positive for the hepatitis $C$ antibody. Rezvan et al . (37) reported that the prevalence of anti-HCV in patients with hemophilia is significantly higher than that in other multitransfused patients. They reported that patients with hemophilia are more susceptible to TTIs, as their treatment is dependent on the use of large-pool coagulation factor concentrates as well as fresh frozen plasma and cryoprecipitate. Although HCV transmission by blood products is prevented by viral inactivation steps now used in the production of plasma-derived factor concentrates, transmission remains a problem in many areas of the world, particularly in developing countries where hemophilia is treated with fresh frozen plasma or cryoprecipitate. Approximately $80 \%$ of individuals using these products are estimated to be HCV infected. Patients with hemophilia thus constitute a high-risk group for acquiring HCV infection (38). We conclude from this study that despite the reduction in the prevalence of HBV and HCV infection among multitransfused children over the past few years, the prevalence remains high in Upper Egypt. More efforts should be made to ensure complete vaccination of children and provide poster doses if needed. Furthermore, blood screening should be performed using more advanced techniques.

\section{Acknowldgements}

None declared.

\section{Authors' Contribution}

Amel Elfaramawy designed the study, analyzed the data and wrote the manuscript.

Omnia El-rashidy revised the manuscript. 
Perihan Tawfik carried out the laboratory part of the study.

Galal Helmy Hussein collected the data.

\section{Financial Disclosure}

The authors declare that they did not receive any financial or technical support for conducting this study

\section{Funding/Support}

None declared.

\section{References}

1. Lopez L, Lopez P, Arago A, Rodriguez I, Lopez J, Lima E, et al. Risk factors for hepatitis B and C in multi-transfused patients in Uruguay.J Clin Virol. 2005;34 (Suppl 2):S69-74.

2. El-Raziky MS, El-Hawary M, El-Koofy N, Okasha S, Kotb M, Salama K, et al. Hepatitis C virus infection in Egyptian children: single centre experience. JViral Hepat. 2004;11(5):471-6.

3. Jain R, Jose B, Coshic P, Agarwal R, Deorari AK. Blood and blood component therapy in neonates. Indian J Pediatr. 2008;75(5):489-95.

4. Feld J, Lee JY, Locarnini S. New targets and possible new therapeutic approaches in the chemotherapy of chronic hepatitis B. Hepatology. 2003;38(3):545-53.

5. Alavian SM, Tabatabaei SV. Immunological response to hepatitis B vaccine in polytransfused thalassemic patients. Pediatr Hematol Oncol. 2010;27(4):324-5; author reply 6-7.

6. Khalifa AS, El-Sayed MH, Moustafa AO, Mohammed MM, Rady MS, Salama II, et al. Hepatitis $C$ virus infection in children with hematological diseases: risk factors and reliability of diagnosis assays. Egypt JPediatr. 2002;19:293-308.

7. Vinelli E, Lorenzana I. Transfusion-transmitted infections in multitransfused patients in Honduras.J Clin Virol. 2005;2(34):S53-60.

8. Mansour E, Abdul-Rahim S, Batouty G, Zaghloul I, Abdel-Hadi S. Integration of hepatitis B immunization in the Expanded Program on Immunization of the Child Survival Project.J Egypt Public Health Assoc. 1993;68(5-6):487-94.

9. Van Thiel DH, Gavaler JS. Response to HBV vaccination in patients with severe liver disease. Absence of an HLA effect. Dig Dis Sci. 1992;37(9):1447-51.

10. Tsouchnikas I, Dounousi E, Xanthopoulou K, Papakonstantinou S, Thomoglou V, Tsakiris D. Loss of hepatitis B immunity in hemodialysis patients acquired either naturally or after vaccination. Clin Nephrol.2007;68(4):228-34.

11. Amarapurkar DN, Kumar A, Vaidya S, Murti P, Bichile SK, Kalro RH, et al. Frequency of hepatitis B, C and D and human immunodeficiency virus infections in multi-transfused thalassemics. Indian J Gastroenterol.1992;11(2):80-1.

12. Abu El-Hassan AM, El-Beshlawy A, Kaddah N, Mostafa A. The frequency of blood born viruses especially HBV, HCV and HIV among Egyptian thalassemic children. New Egypt J Med.1993;8(1-2):135-8.

13. Al-Sheyyab M, Batieha A, El-Khateeb M. The prevalence of hepatitis $\mathrm{B}$, hepatitis $\mathrm{C}$ and human immune deficiency virus markers in multi-transfused patients. J Trop Pediatr. 2001;47(4):239-42.

14. Irshad M, Peter S. Spectrum of viral hepatitis in thalassemic children receiving multiple blood transfusions. Indian J Gastroenterol. 2002;21(5):183-4.

15. Khakhkhar V, Joshi P. HBsAg seropositivity among multi-transfused thalassemic children. IndiJ Patho Microb. 2005;11:432-8.

16. Ocak S, Kaya H, Cetin M, Gali E, Ozturk M. Seroprevalence of hepatitis $B$ and hepatitis $C$ in patients with thalassemia and sickle cell anemia in a long-term follow-up. Arch Med Res. 2006;37(7):895-8.

17. El Gawhary S, Omar N, Abdel Rahman L, Mahmoud M. Hepatic viruses screening in multitransfused Egyptian thalassemia patients. JArab Child. 2009;20(3):193-202.

18. Darwish MA, Faris R, Clemens JD, Rao MR, Edelman R. High se- roprevalence of hepatitis A, B, C, and E viruses in residents in an Egyptian village in The Nile Delta: a pilot study. Am J Trop Med Hyg. 1996;54(6):554-8.

19. El-Zayadi AR, Ibrahim EH, Badran HM, Saeid A, Moneib NA, Shemis MA, et al. Anti-HBc screening in Egyptian blood donors reduces the risk of hepatitis B virus transmission. Transfus Med. 2008;18(1):5561.

20. Khalifa AS, Mitchell BS, Watts DM, el-Samahy MH, el-Sayed MH, Hassan NF, et al. Prevalence of hepatitis $C$ viral antibody in transfused and nontransfused Egyptian children. Am J Trop Med Hyg. 1993;49(3):316-21.

21. EL-Alfy M, EL-Sayed M. Prevalence of hepatitis C among thalassemic children. Egy J Haematol.1997;22(3):311-25.

22. Juneja M, Dubey AP, Kumari S, Prakash C, Mittal SK. Hepatitis B and hepatitis $C$ in multitransfused children. Trop Gastroenterol. 1998;19(1):34-6.

23. Christensen PB, Gronback KE, Krarup HB. [Transfusion related hepatitis C. The Danish "look back" survey]. Klinisk immunologisk afdeling. 2000;162(18):2554-7.

24. Ansar MM, Kooloobandi A. Prevalence of hepatitis $C$ virus infection in thalassemia and haemodialysis patients in north Iran-Rasht. $J$ Viral Hepat. 2002;9(5):390-2.

25. Ramia S, Koussa S, Taher A, Haraki S, Klayme S, Sarkis D, et al. Hepatitis-C-virus genotypes and hepatitis-G-virus infection in Lebanese thalassaemics. Ann Trop Med Parasitol. 2002;96(2):197-202.

26. Rao M, Naficy A, Darwish M, Darwish N, Schisterman E, Clemens J, et al. Further evidence for association of HCV infection with parenteral Schistosmiasis treatment in Egypt" BMC Infectious Diseases. 2002(2):29.

27. Ameli M, Besharati S, Nemati K, Zamani F. Relationship between elevated liver enzyme with iron overload and viral hepatitis in thalassemia major patients in Northern Iran. Saudi Med J. 2008;29(11):1611-5.

28. Mehri GB, Mohammad AA, Khoda MZ, Morteza HR. Prevalence of Hepatitis-C virus (HCV) among Thalassemia Patients in Khuzestan Province, Southwest Iran PakJ Med Sci 2009;25(1):113-7.

29. Hussain H, Iqbal R, Khan MH, Iftikhar B, Aziz S, Burki FK, et al. Prevalence of Hepatitis C in beta thalassemia major. Gomal J Med Sci J. 2008;6(2):123- 45.

30. Bahakim H, Bakir TM, Arif M, Ramia S. Hepatitis $C$ virus antibodies in high-risk Saudi groups. Vox Sang. 1991;60(3):162-4.

31. Al Noomani N, Mahmoud NA, Khalil SN. Seroprevalence of hepatitis $B$ virus, hepatitis $C$ virus, and human immunodeficiency virus infections in patients with hereditary hemoglobinopathies from Saudi. Egyp Liver J. 2011;1(3):97-101.

32. Rahman El-Zayadi A, Abaza H, Shawky S, Mohamed MK, Selim OE, Badran HM. Prevalence and epidemiological features of hepatocellular carcinoma in Egypt-a single center experience. Hepatol Res. 2001;19(2):170-9.

33. Omar N, Salama K, Adolf S, El-Saeed GS, Abdel Ghaffar N, Ezzat N. Major risk of blood transfusion in hemolytic anemia patients. Blood Coagul Fibrinolysis. 2011;22(4):280-4.

34. Medhat A, Shehata M, Magder LS, Mikhail N, Abdel-Baki L, Nafeh M, et al. Hepatitis c in a community in Upper Egypt: risk factors for infection. Am JTrop Med Hyg. 2002;66(5):633-8.

35. Silva LK, Silva MB, Lopes GB, Rodart IF, Costa FQ, Santana NP, et al. Prevalence of hepatitis $C$ virus infection and HCV genotypes among hemophiliacs in the State of Bahia, Northeastern Brazil: analysis of serological and virological parameters. Rev Soc Bras Med Trop. 2005;38(6):496-502.

36. Asif N, Zafar T, Hassan K, Naseem L. Seroprevalence Anti HCV Antibodies, HCV-RNA and its Genotypes among Patients of Hemophilia, at Hemophilia Treatment Centre Pakistan Institute of Medical Sciences, Islamabad. Interl J Patho. 2009;7(2):84-7.

37. Rezvan H, Abolghassemi H, Kafiabad SA. Transfusion-transmitted infections among multitransfused patients in Iran: a review. Transfus Med. 2007;17(6):425-33.

38. Giangrande PL. Hepatitis in haemophilia. $\mathrm{Br} J$ Haematol. 1998;103(1):1-9. 